\title{
THE PLACE OF THE TURKISH INDEPENDENCE WAR IN THE AMERICAN PRESS (1918-1923)
}

\author{
BÜLENT BILLMEZ
}

\author{
"The only true history of a country is to be \\ found in its newspapers" \\ Macaulay ${ }^{1}$
}

\begin{abstract}
This paper examines some American periodicals published between 1918 and 1923. According to this examination, he foremost topics discussed in these periodicals in this period were as follows: the plans for a 'new order' in the region and the role of the USA in this new phase; the question of Christian minorities, expecially the Armenians and American missionaries in Turkey; the war between the Turkish and Greek armies; Kemalists' links with the Bolsheviks and Islamism; the negoiations at Lausanne and discord among the Allies, and the ec nomic, commercial and cultural interests of the USA in the "new Turkey".

I conclude that the attitude of the American press, in general, changed slowly but continuously during this period, and was determined strongly by the attempts of the Kemalists to prove how 'modern' or 'Westernized' they were. Although anti-Turkish discourse remained dominant even afer the Treaty of Lausanne, a more analytical and objective view of the Kemalists started to prevail.
\end{abstract}

\section{KEYWORDS} Relations.

Turkish Independence War; US Press; Turkish Image; US-Turkish

${ }^{1}$ Cited by Chandrika Kaul, "The Press", in B. Brivati, J. Buxton \& A. Seldon (eds.), The Contemporary History Handbook, Manchester \& New York, Manchester University Press, 1996, pp. 298-310. 


\section{Introduction}

\section{The Subject}

The history of the Turkish Independence War (TIW) is an important part of a more general subject: the ultimate settlement of the so-called "Eastern Question". This is the question how to solve the problem created by the continuing territorial erosion of the Cittoman Empire during the whole $19^{\text {th }}$ century and the first quarter of the $20^{\text {th }}$ century. The emerging nationalist movements in the Balkans, which led to the formation of new states (Serbia and Cireece) on one side, and the battle defeats of the Ottoman armies by the "Great Powers" of that time on the other, caused gradual loss of more and more pieces of land. As the "fall" of the Empire as a whole was then in question, the government, order of the regions under the control of the Ottoman Empire, and the possible partition of these regions became the most important question among the Great Powers.

Because the Great Powers had difficulty in making and realizing any decision about this partition, due to the severe competition among them, this problem has remained as the most important question of the pre-First-World-War era. One can even say that one of the reasons for the delay in the expected fall of the Empire was this very competition, which led to the First World War (WWI), or the "Great War".

The Eastern question was to be solved ultimately during and after the WWI, but immediately after the war the question became mainly a "Turkish Question". The new regulations for the formerly Ottoman countries were planned through hard bargaining by the "winners" of the War at the diplomatic negotiations in the dominant centers of the Great Powers. The plans of the winners for Turkey, however, were disapproved and opposed by a group of "nationalist" Ottoman soldiers, who managed to gain the support of different social and ethnic groups in Turkey. While the other aspects of the old Eastern Question (in the Balkans, Arab countries) were being settled by the agreements after the War, this very opposition in Turkey under Mustafa Kemal's leadership generated a resistance movement against the plans of the Great Powers for Turkey. This movement was to form a regular army under the commandment of the old Ottoman officers, and fight against the Greek army, which 
in May 1919 occupied a part of the country with the encouragement of English politicians.

The struggle of the Kemalists between 1919-1923 to form a new state, and the war between the Greek and Turkish armies in years 1919-1922 are commonly called the Turkish Independence War (TIW). This movement was the most important part of the settlement of the "Turkish Question", although the Western politicians had been trying to "solve" this question at the diplomatic meetings by ignoring this local initiative and dictating their plans to the Ottoman elite, and by trying to avoid any further military confrontation in the region.

So, we can see the question of the TIW as a part of the settlement of the Turkish Question after the War and consider this settlement as an important part of the ultimate settlement of the old Eastern Question. This study of the American press in this period focuses on this general question (i.c. Eastern Question). That is why the statistical information given in this paper is about the place of this general question in the American press, though the place of the Turkish Question (i.e., TIW) in the American press of that time will also be discussed. Three questions came to mind when discussing such an issue:

1) How, if at all, was American foreign policy towards Turkish Question influenced by the American press? As the main assumption here is that we may find out the American state policy towards the Kemalists by using published documents and secondary literature, ${ }^{2}$ we can do his by comparing US policy with the attitude of the press. To do this, we should discuss the role of press in foreign policy making, and policy making in general, ${ }^{3}$ but this is not one of the aims of this paper. ${ }^{4}$

${ }^{2}$ See footnotes $47-48$ below.

3 "The press also acts as a participant in the policymaking process. ... the press fulfills this role by serving as representative for the public, government watchdog or critic, advocate of certain policy positions, and actual policymaker." Richard Davis, The Press and American Politics, New York \& London, Longman, 1992, pp. 197-198.

${ }^{4}$ For the general discussions on the press and the American foreign policy see: Davis, especially part IV "Media and Policy", pp. 195-234; Bernard Cohen, The Press and Foreign Policy, Princeton, N. J.: Princeton 
2) How far is the American press usable as a "source" in writing the history of the TIW (or the history of the ultimate settlement of the Eastern Question) and especially the history of Turkish-American relations of that time?

3) What was the attitude of the American press towards the TIW and Kemalists in general? Or to put it differently: what was the place of the TIW in the American press? The attitude of the American press may be considered as the "attitude of the American public opinion" as well, for "the press can be viewed by policymakers and the public as the voice of public opinion." 5 Hence, the purpose of this paper, in the most general terms, is to discuss the place of the Turkish Question (1918-1923) in the American opinion. To do this, a brief account of the press used for this study should be given first.

\section{The Scope of the Materials: American Press from the End of 1918 to the End of 1923}

The press "as a collective noun covers a wide variety of publications, at national, provincial and local levels, each with its own distinctive characteristics. It is most commonly understood to refer to the national (and provincial) dailies, as well as the weekly magazines of current and political affairs." 6 Number of weekly, monthly and quarterly periodicals were used in this research, and the term the "American press" refers to these periodicals. One of the reasons for this is a very practical one: until now I have only had access to the issues of these periodicals. The other reason is rather methodological, as the journals are more proper than the daily newspapers to study the attitude of the press in a certain

University Press, 1963; Stephen Hess, The Government/Press Connection, Washington, Brookings, 1984; Nicholas O. Berry, Foreign Policy and the Press; an Analysis of The New York Times Coverage of US Foreign Policy, New York; Greenwood Pr., 1990; James Playsted Wood, Magazines in the United States; Their Social and Economic Influence, New York; The Ronald Press Co., 1949; and Martin Linsky, Impact: How the Press Affects Federal Policymaking, New York, W. W. Norton, 1986.

5.Davis, The Press and American Politics, p. 198.

${ }^{6}$ Kaul, "The Press", p. 299. 
period, because "most journal articles establish their argument by outlining and encapsulating the literature on the topic concerned, and this may be a quick and useful introduction to the historical discourse on the subject. Certain periodicals deal largely with issues relevant to contemporary history."7

Some statistics on the number of the articles published in some of the American periodicals of this time will be given, and they will be used to supply a general picture of the subject. Besides giving a general picture of the number of articles on the Eastern Question in the American press, the paper will offer some general observations driven from the content of the articles studied and from the study of one daily newspaper; the New York Times (NYT).

Hitherto I have searched 7 American periodicals of that time and collected 338 articles on the Eastern Question. The titles of the periodicals I have studied and the abbreviations I use for them in this paper are; Asia [A], Current History [CH], Foreign Affairs [FA], The North American Review [TNAR], The New Republic [TNR], Political Science Quarterly [PSQ], The Atlantic Monthly [TAM].

Table 1 (p. 56) shows some very general information on these periodicals.

$[\mathrm{CH}]$ and $[\mathrm{A}]$ are those periodicals that I have examined most thoroughly, because they are those, which were so much interested in the Eastern Question, that we can follow, though partly, its history even only by using them. Up to now I have collected all issues of $[\mathrm{CH}]$ and $[\mathrm{A}]$ from the end of the war (November 1918) to the end of 1923 (the year in which Turkish Republic was founded). We can find almost in every issue of [CH], during this time, articles on the Eastern Question. Another magazine, all issues of which for this period I have examined is [FA], but this quarterly magazine was established in September 1922, so just one and a half years are in question and a total of 6 issues were published in this time. I have not examined all issues of the other periodicals, but have collected some articles from

\footnotetext{
${ }^{7}$ M. D. Kandiah, "Books and Journals", in B. Brivati, J. Buxton \& A. Seldon (eds.), The Contemporary History Handbook, Manchester \& New York, Manchester University Press, 1996, p. 321.
} 
Table 1: General Information About the Periodicals Used for this Paper.

\begin{tabular}{|c|c|c|c|c|c|c|c|}
\hline Title(abr.) & {$[\mathrm{A}]$} & {$[\mathbf{C H}]$} & {$[\mathbf{F A}]$} & [TAM] & [TNAR] & {$[$ TNR] } & [PSQ] \\
\hline Frequency & monthly & monthly & quarterly & monthly & monthly ${ }^{a}$ & weekly & quarterly \\
\hline City & New York & New York & $? ? ?$ & Boston & New York & New York & New York \\
\hline Established & 1917 & $1914^{b}$ & 1922 (Sept.) & 1857 (Nov.) & $1815-1918^{c}$ & 1914 (7 Nov.) & 1887 \\
\hline Description & $\begin{array}{c}\text { lit. \& } \\
\text { geographical }\end{array}$ & $\begin{array}{l}\text { current } \\
\text { events }\end{array}$ & $? ? ?$ & literary & $\begin{array}{l}\text { review of the } \\
\text { world events }\end{array}$ & \begin{tabular}{|c|} 
current \\
comment \& \\
review
\end{tabular} & $\begin{array}{c}\text { political } \\
\text { science }\end{array}$ \\
\hline Subscr. (\$) & 4.00 & 3.00 & $? ? ?$ & 4.00 & 4.00 & 5.00 & 5.00 \\
\hline Circ. (1925) & 62.337 & 80.311 & N.A. & $121.987^{\mathrm{d}}$ & 9.469 & 300.00 & 5.000 \\
\hline Editor(s) & L. D. Froelick & ??? & ??? & E. Sedgwick & $\begin{array}{l}\text { E. B. Cutting } \\
\text { \& Assoc. }\end{array}$ & $\begin{array}{l}\text { H. Croly \& } \\
\text { Assoc. }\end{array}$ & $\begin{array}{c}\text { Fac. of Pol. Sci. } \\
\text { of Colom. } \\
\text { Univ. }\end{array}$ \\
\hline Publisher & $\begin{array}{l}\text { Asia Magazine } \\
\text { (Inc.) }\end{array}$ & $\begin{array}{l}\text { N. Y. Times } \\
\text { Co. }\end{array}$ & ??? & $\begin{array}{c}\text { Atlantic } \\
\text { Monthly Corp. }\end{array}$ & $\begin{array}{l}\text { North Amer. } \\
\text { Rev. Corp. }\end{array}$ & $\begin{array}{c}\text { Republic Pub. } \\
\text { Co. (Inc.) }\end{array}$ & $\begin{array}{c}\text { Academy of Pol. } \\
\text { Sci. Pub. }\end{array}$ \\
\hline
\end{tabular}

Source: Alan Nourie \& Barbara Nouire (eds.), American Mass Market Magazines, New York, Greenwood Pr., 1990; N. W. Ayer and Son's American Newspaper Annual \& Directory, A Catalogues of American Newspapers, Philadelphia, Ayer, 1925; Henry Ormal Severance (ed.), A Guide to the Current Periodicals and Serials of the United States and Canada, 1920; Frank Luther Mott, "Periodicals - United States", in Encyclopedia Americana, New York, Americana Co., 1966, pp. 591-594; Frank Luther Mott, A History of American Magazines, Vol. II-V., 1885-1905, Cambridge, Harvard University Press, 1938-1968; and the periodicals themselves. a It is stated in N. W. Ayer and Son's American Newspaper Annual \& Directory, that this periodical is "quarterly", but Severance, A Guide to the
Current Periodicals, remarked it as "weekly". However issues from 1921,1922 and 1923 that I have examined are all monthly. No information thereupon is to be found for the time between 1907-1927 in Daniel Starubel, "North American Review", Nourie/Nouire, American Mass Market Magazines, p. 338.

$\mathrm{b}_{\text {It }}$ is stated in Severance, A Guide to the Current Periodicals, as "1917".

It is said in Severance, A Guide to the Current Periodicals. that the periodical changed its owner in 1918 and started being published weekly.

$\mathrm{d}$ "... sales surpassed 100.000 in 1921." Jean M. Parker, "Atlantic Monthly", in Nourie/Nouire, American Mass Market Magazines, p. 37.

e"George Harvey was editor and owner from 1899 to 1926". Mott, "Periodicals - United States", p. 592. The same information can be found in Starubel, "North American Review", p. 338 
different years in this period. Yet I will use all of these articles to derive some general observations on the attitude about the Eastern Question in the American press of that time. Another source for these observations will be the articles in the well known daily newspaper The New York Times [NYT], which were translated into Turkish and published in Osman Ulagay's book in $1974 .{ }^{8}$

\section{Methodological Framework: The American Press as a Potential Source in History Writing of TIW.}

The history of the Turkish Independence War (1919-1923) (TIW) in general and of many specific aspects of it have been studied by numerous scholars by using different sources. I do not aim in this paper to re-write this history by using the American press of that time, but it may be worthwhile to discuss whether the American press can be used as a "source" for this purpose, or for writing any historical subject at all, and if so, to what extent.

At the outset it seems worthwhile to state clearly that I consider the press to be one of the most important sources for contemporary history writing. We do not need to discuss here the importance of the press as a "source" in history writing as historians are all very well aware of this and they have been using it continuously. One of the most distinguished of them, Eric Hobsbawm puts it very clearly: "As the historian of the twentieth century draws closer to the present he or she becomes increasingly dependent on two types of sources: the daily or periodical press and...publications by national governments and international institutions." 9 This role of the press is emerging from the fact that "the press does serve as observer in society - recording events, statements and policy decisions." 10 Apart from its importance, we may discuss whether we can consider the American press as a '"primary" source or not, and whether we can see it as a document (Überreste) or rather as a narrative (a source of Tradition). Doing

\footnotetext{
${ }^{8}$ Osman Ulagay, Amerikan Basınında Türk Kurtuluş Savaşı, İstanbul, özel yayın, 1974.

${ }^{9}$ Eric Hobsbawm, The Age of Extremes, London, 1994, p. xi.

${ }^{10}$ Davis, The Press and American Politics, p. 198.
} 
this, as Brandt puts it in his classic book, ${ }^{11}$ we should know that such classifications are only meaningful, if we keep in mind that "Eine absolut geltende, d.h. philosophisch-logisch einwandfreie Gruppierung des historischen Quellenstoffes ist nicht möglich und wäre auch sinlos..."12

One way of classification of the resources is to divide them into "primary" and "secondary" ones. But again we should not forget that this is a completcly relative criterion, i.e., one source may be relatively "more" or "less" primary than another under different circumstances. Besides, primary sources are not by definition always more useful than secondary ones. The American press of that time, for instance, can be seen as a primary source in writing the history of 1920 's compared to the books and articles written in the later years, but the records of the diplomatic correspondence, for example, are "more primary" than the press. Nevertheless, the American press is for instance, the "most primary" source for writing on such subjects as the attitude of the American press towards the Turkish nationalist movement, or towards Turkey in general.

Another commonly accepted classification of historical sources is made according to thcir endogenous characteristics (innere Eigenschaften): The sources that inform us about history unintentionally (unabsichtlich, 'unwillkürlich') are called "documents" (Überreste), and those do this intentionally (willkürlich) and with the purpose of informing on history (zum Zweck historischer Kenntniss) are called "narratives" (Tradition) ${ }^{13}$. One "source" may be considered as "document" or "narrative" depending on the reasons it is used, and it may even be used as both at the same time. In this context, the American Press, for instance, is "written narrative", when one aims at using it to write the history of the Turkish-American relations, because the purpose of the press is to reflect the contemporary history of this subject in this time as the information in the press is a kind of report on the contemporary developments. In this case, the subjectivity of this

\footnotetext{
${ }^{11}$ A. V. Brandt, Werkzeug des Historikers, Stuttgart, Verlag W. Kohlhamer, 1998. Also See E. Boshof, K. Düvell \& H. Kloft, Grundlagen des Studiums der Geschichte, Köln, Böhlau Verlag, 1994.

${ }^{12}$ Brandt, ibid., pp. 49-50.

${ }^{13}$ Cited from E. A. Freeman by ibid., p. 61.
} 
source may be a big problem for a historian. Therefore any historian intending to use the press for understanding and/or reflecting a historical subject must always take this problem into consideration very seriously. ${ }^{14}$ However this very source may be considered, on the other hand, as "document", if one wants to study a subject like "the attitude of the American press towards the Kemalist movement" or "the image of Turkey or Turks in the American press". Because the aim of the creators (Erzeuger), i.e., the authors, in this case is not to give us answers to the questions about these subjects. In this case, they are themselves a part of the history.

We can say, in this context, that the daily newspaper The New York Times [NYT], for instance, can be utilized to follow the developments in the Near East, because the newspaper was very interested in the region and reported almost every important event there. However it would be misleading not to check the accuracy of the given information carefully because as a daily newspaper, it often informs us about something, developments about which are not written at all in the following days, and which we today know that was completely incorrectly reported. Though we may sometimes find news in periodicals or newspapers on events we never have come across before, we should always check the accuracy of it by using "conventional" sources. A good example for this is news item in the June 1923 issue of Current History $[\mathrm{CH}]$, where an interesting initiative of a Swiss group at the peace conference in Lausanne is mentioned:

While the Turkish delegation at Lausanne was engaged upon the weighty problems of the Near East peace, it received on May 12 a proposal which at first sight did not appear altogether serious, but on consideration was found to have certain advantages. A Swiss syndicate proposed to the Turkish Government through Ismet Pasha, an exclusive concession for the export of pure blood Angora cats, which could be bought at less than \$1 each and sold in America, England and elsewhere for at least $\$ 50$ each $(\mathrm{CH}, 1923 / 6: 532) .{ }^{15}$

${ }^{14}$ For the two dimensions of this question, choosing (Auswahl) and evaluation (Wertung) see ibid., pp. 62-63.

${ }^{15}$ For the references to the periodicals of that time, I use the following method: the abbreviation of the periodical is followed by the year of the publication, and this is followed by the number of the month after a slash (/) and the page is given after a colon: [abbreviation],[year/month]:[page]. 
This stimulating news definitely needs to be confirmed by other resources, but it may be the initiator of an interesting discovery: Since I found the same information in TNR,1923/6/ 13:58 as well.

The study of the news on TIW in the [NYT] and the periodicals of that time may serve as a very good subject for a case study, to argue how far the press can be used to write history. We may assert that the more frequently a press organ appears the less accurate the information it supplies: The information in the short news articles in every issue of the weekly periodical [TNR] under the title of "The Week", in which the recent developments in the world were briefly summarized is, for instance, more accurate than that in the daily news in the [NYT]. But the information in the regular news articles published in monthly magazines like [A], [TAM] (under the title of "The New World") and [CH] (under the title of "The events of the last month") is much more accurate than that in the [TNR], and less accurate than that supplied in the quarterly magazines [PSQ] (under title of "The New World") and [FA]. Apart from news articles, we may find analytical articles with very precise examinations of the developments in the region. The reason for this negative relation between the accuracy of the information and the frequency of the press organ is very simple: the monthly and weekly periodicals have more time to check the accuracy of the information about the events, which daily newspapers may write without deeper investigation into the accuracy of the information. However the basic goal of the monthly periodicals is not to reflect the developments through news articles, but to offer deeper evaluations and discussions by prominent opinion makers of the society. Because of this reason the periodicals would help us much to find out the public opinion at any particular time.

However the press organs (daily, weekly or monthly) are not only "reflectors" of the public opinion, but they take an important part in the "making" of this very public opinion. The degree of this

So, for instance, $\mathrm{CH}, 1923 / 6: 532$ refers to the page 532 of the June issue of Current History in 1923. For the daily newspapers and weekly magazines, the exact day of the publication is indicated after the number of the month: [abbreviation],[year/month/day]: [page]. 
influence is rather a questionable issue and the role of the press as a policymaker can be discussed somewhere else, but this is not the proper place for this discussion.

\section{Some General Observations}

The materials I used for these general observations are mainly the articles I have collected when I searched the American periodicals, a table of which is given above.

The table below shows the number of the articles published in each of these periodicals in every year of the period under consideration:

Table 2: Number of the articles about the Eastern Question published in some of the American periodicals in years 19181923.

\begin{tabular}{|l|c|c|c|c|c|c|c|c|}
\hline & CH & A & PSQ & TNAR & FA & TNR & TAM & TOTAL \\
\hline $\mathbf{1 9 1 8}$ & 4 & 3 & $\mathrm{x}$ & $\mathrm{x}$ & n.p. & $\mathrm{x}$ & $\mathrm{x}$ & 7 \\
\hline $\mathbf{1 9 1 9}$ & 23 & 9 & $\mathrm{x}$ & $\mathrm{x}$ & n.p. & $\mathrm{x}$ & $\mathrm{x}$ & 32 \\
\hline $\mathbf{1 9 2 0}$ & 38 & 8 & 1 & $\mathrm{x}$ & n.p. & $\mathrm{x}$ & $\mathrm{x}$ & 47 \\
\hline $\mathbf{1 9 2 1}$ & 37 & 5 & 1 & 1 & n.p. & $\mathrm{x}$ & $\mathrm{x}$ & 44 \\
\hline $\mathbf{1 9 2 2}$ & 77 & 17 & $\mathrm{x}$ & 1 & 1 & 11 & 1 & 108 \\
\hline $\mathbf{1 9 2 3}$ & 51 & 8 & 3 & 4 & 8 & 18 & 8 & 100 \\
\hline TOTAL & 230 & 50 & 5 & 6 & 9 & 29 & 9 & $\mathbf{3 3 8}$ \\
\hline
\end{tabular}

n.p. = the periodical was not published in that year. $\mathrm{x}=$ no information about the issues in this year is available.

The graph below, which is driven from the table above, shows us the change in the interest of these periodicals for the Eastern Question: ${ }^{16}$

\footnotetext{
${ }^{16}$ The table shows only the "nominal" place of the Eastern Question in these periodicals. To show the "real" place of this subject in the press and the relative change every year, we should be able to give the proportion of the place this subject took in every issue of each periodical used.
} 
Figure 1: Change of Interest Towards Eastern Ouestion in American Periodicals, 1918-1923

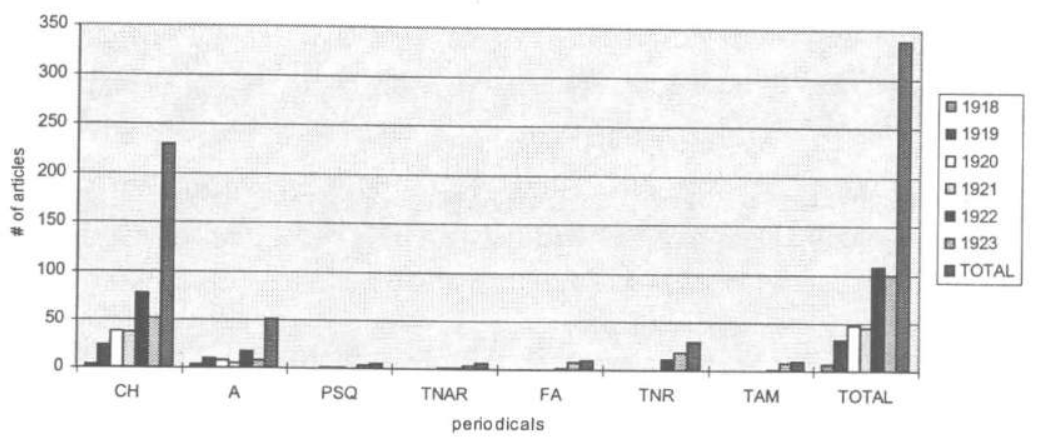

As we can see from the graph above, the periodicals were interested for the Eastern Question the most in 1922 (108 articles), which actually is understandable, for this was the year when the determining war between the Greek and Turkish armies took place. However it is worth discussing whether or not this growth of interest was due to the general sensitivity of public in the West to Greek concerns; because the increasing trend in this period seems to diminish after the end of the war in Autumn 1922, although the settlement of the Turkish Question was not completely fulfilled. We can see from the table that the number of the articles in 1923 (100 articles) is slightly less than that in the previous year (108 articles), which shows that the interest in 1922 generally was sustained for this year, though the trend seems to diminish. After this brief information about the quantitative side of the subject, it is now possible to introduce some general observations about the content of the articles and the news articles in the [NYT] during this period.

\section{An Overview Based upon the Information Derived from all} of the Articles in the Periodicals and the NYT (1918-1923)

1. The American press in general was very much interested in the World War from the beginning, although the USA did not take part in the war until April 1917. The most important subject in the press in the last months of the war was the developments in the 
new socialist state of the Bolsheviks in Russia and victories of the Allies on different fronts including those in the Ottoman Empire. ${ }^{17}$

The reports and analyses about the World War continued to be published in the following years as well. ${ }^{18}$

2.The interest of the press after the end of the war focused on the international negotiations that took place immediately after the war. ${ }^{19}$ Though there was a discussion in the USA about whether the state should play an active role in these negotiations, the general expectation was that the USA must profit from the advantages of being on the side of the "winners", i.e., should take her share of the "spoils" of the war, since they had played a determining role during the war. Therefore, we can read an extensive story of these negotiations about the new arrangements in the world in the November and December 1918 issues of the [NYT], $[\mathrm{A}]$ and $[\mathrm{CH}]$. The most important subject then and in the first months of 1920 was the Versailles negotiations in Paris, and the developments in Germany and in the new states of Eastern Europe. ${ }^{20}$

${ }^{17}$ See for examples Current History, Vol. 8, April - September 1918.

${ }^{18}$ See for example A,1918/11: "The Mesopotamian Campaign" by F. Maurice; CH,1918/11: "Mesopotamian Operations"; CH,1918/12: "Story of the Capture of Damascus" by W. T. Massey; CH,1919/02: "War Casualties of all Nations" by W. Littlefield and CH,1920/06: "The Costs of War" (anonymous). The interest for the near history of Turkey, especially her relations with Germany in the years of the World War continued: $\mathrm{CH}, 1920 / 03$ : "Turkey's Coercion by Germany" (anonymous); CH,1920/04: "Constantinople under the Germans" (anonymous).

${ }^{19}$ Actually the discussions on the possible developments after the war, in case the Allies were to win, were to be seen in the press in the last months of the war as well. See for examples CH, Vol. 8, April - September 1918.

${ }^{20}$ The title on the cover page of the November issue of the $[\mathrm{CH}]$ was "Peace" and two of the other subjects on the cover were "Bulgaria's Surrender and Turkey's collapse (official reports)" and "America's Brilliant Fighting". See also $\mathrm{CH}, 1918 / 12$, cover story of which is "End of the War" and the developments in East Europe and Germany. All issues of $[\mathrm{CH}]$ in the year 1919 and 1920 included extensive information on the new political, economical and diplomatic events and developments in Europe, especially in the Bolshevik Russia and East Europe. See: CH, Vols. 9, 10, 11 and 12 . 
3. The defeat of the Ottoman armies on different fronts and the surrender of the Empire were cheered by the press, and the Mudros Armistice on October 30, 1918, was reported promptly. ${ }^{21}$

4. The foremost issues discussed during the two years after the war were plans for a "new order" in the region, in which the Ottoman Empire had dominated until then, ${ }^{22}$ and the role of the USA in this new phase. ${ }^{23}$

4a. At the outset, the question of the Christian minorities, ${ }^{24}$ especially the Armenian Question, had a clear priority in the press. ${ }^{25}$

${ }^{21}$ The "text of terms under which Turkey laid down her arms" was published in CH,1918/12: "Turkey's Surrender to the Allies" (anonymous). The cover of this issue of $[\mathrm{CH}]$ was titled as "Victory. End of the War".

${ }^{22} \mathrm{CH}, 1918 / 11$ : "Reconstructing Turkey" by W. H. Hall; A,1918/12: "Rearranging the Near East" by H. C. Woods; $\mathrm{CH}, 1919 / 01$ : "Istanbul Occupied" by C. H. Owen; A,1919/02: "England and her Eastern Policy" by H. Sidebotham; 1919/03: "The Derelict Turkish Empire" by V. Chirol; A,1919/05: "The Near East in Liquidation" by E. G. Tabet: CH,1919/07: "The Turks and Bulgars at Paris" (anonymous); A,1920/01: "Zero Hour in the Near East" by Jackson Fleming; CH,1920/03: "The Partition of Turkey" (anonymous); CH,1920/05: "The Problem of Trace" by J. F. Scheltema; CH,1920/06: "The Dismemberment of Turkish Empire" (anonymous): CH,1920/06: "The San Remo Conference" (anonymous); CH,1920/06: "The Dangerous Situation in Asia Minor" (anonymous).

${ }^{23}$ A,1919/02: "Should America Act as Trustee of the Near East?" by L. D. F.

${ }^{24} \mathrm{CH}, 1919 / 03$ : "Massacre of the Greeks in Turkey" (anonymous); $\mathrm{CH}, 1919 / 6:$ "Greeks in the Balkans and Asia Minor" (anonymous); CH,1922/09: "Mustafa Kemal and the Christians" by C. Price; CH,1923/03: "The Greek Ecumenical Patriarchy in Turkey" by C. Price .

${ }^{25}$ See A,1919/04: "Armenia Resurrected" by I. D. Levine; CH,1919/04: "New Territorial Problems in Asia - Armenia" (anonymous); CH,1919/10: "Turkey and Armenia" (anonymous). In November 1919 there was an article published in $\mathrm{CH}$ about the so called "Armenian Massacre' and Germany's role in it "Germany and Armenian Massacre" (anonymous). For the articles in the later months on the Armenian Question see CH,1920/01: "Armenia's Struggle for Independence" by W. D. P. Bliss; 1920/05 "General Harbord's Report on Armenia" (anonymous); CH,1920/06: "Some Facts about Armenia" by B. B. Moore; CH,1920/07: "The Conspiracy Against Armenia" (anonymous); "Armenia Overwhelmed be Enemies" (anonymous); CH,1921/07: "Why Talaat Pasha's Assassin was Acquited" by G. R. Montgomary; CH,1921/08: "Armenian Muss" by 
4b. From the beginning, the press was very much interested in the conditions of the American missionaries in Turkey, and their fate in the future.

4c. The readers were informed extensively about the proposal for an American mandate in the region, and opinions for and against the American Mandate found their space in the magazines. ${ }^{26}$

5. After the second half of 1919 , the favorite topic in the American press was the Greek occupation of İzmir an,d western Turkey. The active support of the "Great Powers" for this occupation was legitimized in the press by the argumentation that the Greeks were representing "civilization" there! They were introduced as the soldiers of the "civilized" West, and it was expected from them that they should punish the "barbarian" Turks and help the Western powers to save the Christian minorities and to bring civilization to the Turks.

A. Mahdesian; CH,1921/11: "Posthumous Memories of Talaat Pasha" (anonymous); 1922/02: "Saving 40.000 Armenians" by D. S. Nortcote; $\mathrm{CH}, 1922 / 10$ : "The Massacres of the Armenians in 1915" by G. R. Montgomary.

${ }^{26}$ A,1919/12: "Mandates for Turkish Territories" by J. Flemming. The January 1920 issue of [A] was basically on the "Near East" and one of the titles on the cover page was "A Mandate -Does America Qualify?" This question was discussed in this issue by Talcott Williams in his article "The American Idea in the Near East" and by Louis D. Froelick in the article titled as "Focusing on Mandates". The attitude of the [NYT] towards this question was to advocate the American mandate in Armenia and Turkey, and the Turks were introduced as the "uncivilized, barbarian murderers" against whom the Armenians should be saved. After the negative approach towards an American mandate in the General Harbord's report on the situation of the region (See CH,1920/05: "General Harbord's Report on Armenia"), the hope of an American Mandate seems to be lost: $\mathrm{CH}, 1920 / 07$ : "No American Mandate for Armenia" (anonymous). However, the supporters of an American mandate for the region did not give up their opinion and the press continued to publish articles on this question: A,1921/07: "American Rights and Interests in the Mandatory System" by F. F. Andrews, "The Potential Advantages of the Mandate System" by J. Addams and "The Defects of the System of the Mandates" by H. A. Gibbons. 
6. Besides the Greek occupation, the immediate opposition against it under the leadership of Mustafa Kemal was reported intensively, ${ }^{27}$ whereas the attitude towards this nationalist movement, about which the press initially did not know much, was very negative: at the beginning they were considered as the offspring of the Young Turks, that had been seen as the persecutors and executioners of the Armenians, and as the friends of the Bolsheviks and Islamists. As we will see below, the Kemalists were to be taken more seriously later, but at the beginning they were seen as a group of adventurers and radicals. They were often reported as bandits or gangs that were fighting against the civilized West. This attitude would remain to the end, but some alternative opinions would gradually find more place in the press, and the readers were informed about the Kemalist movement and Turkey more regularly and more respectfully after the press began to see that they were taken seriously in the region and in the capital cities of the West, ${ }^{28}$ though the anti-Turkish tendency was dominant even after the end of the war.

7. For the anti-Turkish campaign, basically in the [NYT], the statements of Henry Morgenthau, the former American ambassador in the Ottoman Empire, were often utilized. He always engaged in a radical discourse against the Turks and advocated the clirect control of the region by the Americans to save the Christian

${ }^{27} \mathrm{CH}, 1920 / 04$ : "Dangerous Complications in Syria Massacres at Marash" (anonymous); CH,1921/01: "Gains of Turkish Nationalism" (anonymous)

${ }^{28} \mathrm{CH}, 1921 / 08$ : "Mustafa Kemal and the Greek War" by C. Price; A,1922/03: "Conversations With a Kemalist" by Demetra Vaka; A,1922/04: "The New Turkey of Mustapha Kemal" by L. S. Moore; CH,1922/04: "The Turkish Government in Angora" by M. Zekeria; CH,1922/07: "Kemal Pasha Creator of a New Turkey" by C. Price; CH,192/08: "Mustafa Kemal and Angora Government" by C. Price; CH,1922/09: "Turkey Reinterpreted" by M. Chester; CH,1922/11: "Turkey's National Pact" (anonymous), "How Mustafa Kemal Formed his Army" by E. Harris, and "Kemal Pasha" by C. Price ; 1922/12: "The New Turkey" C. Price; FA,1922/11: "A Note on the Political Map of Turkey" I. Bowman ; $\mathrm{CH}, 1923 / 02$ : "Foreign Policy of the New Turkey" by C. Price and ""Angora and the Turks" by A. T. Chester; TNR,1923/06/27: "Angora" by A.Toynbee; CH,1923/10: "History's Verdict on New Turkey" by A. T. Chester and "Angora, Cinderella Metropolis of Turkey" by A. Toynbee; TAM,1923/10: "Turkey and East" (anonymous). 
minorities (i.e., Greeks and the Armenians) from the "massacres" 29 and "cruelty" 30 of the barbarian, brutal Turks and to save the interests of the American missionaries in Turkey. ${ }^{31}$

This attitude of Morgenthau continued to the end of (and even after) the war, and he kept opposing any attempt to come to an understanding with the Turks. ${ }^{32}$

Another way of reflecting this anti-Turkish attitude was to publish letters to the editor, in which the Turks were attacked severely. ${ }^{33}$

8. After the foundation of a regular army by the government founded in the parliament in Ankara, and especially after the first successes of this army against the Greek army, which terminated their move towards inner Anatolia, the war between the Turkish and Greek armies started to be seen as a fight between two regular armies of countries in the "periphery". The press reported the developments on the front on a regular basis, without giving up the habit of standing behind the Greeks and giving hope to the readers that the Turks were ultimately to be defeated soon. ${ }^{34}$

\footnotetext{
${ }^{29} \mathrm{CH}, 1919 / 3: 549$.

${ }^{30} \mathrm{CH}, 1919 / 1: 89$.

${ }^{31}$ NYT,1918/11/6; NYT,1918/11/7; NYT,1919/5/24; NYT,1919/10/18 etc. ${ }^{32}$ NYT, $1923 / 1 / 10$ and NYT, 1923/7/28.

${ }^{33}$ See for example NYT,1919/12/22; CH,1921/02 by S. Derenian.

${ }^{34} \mathrm{CH}, 1920 / 09$ : "The Greeks in Asia Minor" (anonymous); $\mathrm{CH}, 1921 / 02$ : "Fightings in Smyrnia and Syria" (anonymous); CH,1921/06: "What Greeks are fighting for" (anonymous); $\mathrm{CH}, 1921 / 07$ : "Fighting the Turks at Anatolia" by L. Shepard; CH,1921/08: "Why the Greeks are Fighting Turkey" by A. Th. Polyzoides and "Greek Mobilization not Suspended" by E. A. Gregory; $\mathrm{CH}, 1921 / 09$ : "The Greek Triumph in Turkey" (anonymous); CH,1921/10: "The Great Battle for Angora" (anonymous) and "The Passing of Turkey" by A. Th. Polziodes; CH,1921/11: "The War in Anatolia" (anonymous); CH,1921/11: "Setback for Greece in the Near East" (anonymous) and "The Curious Muddle of the Greco-Turkish War" (anonymous); CH,1922/01: "The Greek Campaign of 1921" by A. Th. Polyziodes; CH,1922/03: "What Greece Has Won from Turkey" by D. P. Gournanis; CH,1922/05: "Greece and the War in Asia Minor" (anonymous); CH,1922/10: The Grecks' Collapse in Asia Minor" by A. Th. Polyziodes and "The Turkish Triumph over Greece" (anonymous); CH,1923/05: "Greek Defeat in Turkey" by M. Tsamados.
} 
Beside the military adventure of the Greeks in Asia Minor, the press was interested in the internal political developments in Greece. ${ }^{35}$

9. One of the tense subjects in the press was the relation between the Kemalists and the Bolsheviks. ${ }^{36}$ In the first years, the authors of the articles with an anti-Turkish bias were sure that the Kemalists were Bolsheviks or collaborating with them to fight aggainst the capitalists.

10. Another issue, in which the press seemed to be interested was the link between the Kemalist movement and the Muslim countries and there was a tendency of relating the Turkish Question with the problem of Islamism and Islam in general. ${ }^{37}$ This subject was actually in question since the end of the war. It was discussed, together with the question of the fate of the Caliphate, to the end of the settlement of the Turkish Question. ${ }^{38}$ In this context, the possible reaction of the Muslims in the British colonies was often argued and the danger of a general Islamic

${ }^{35}$ CH,1921/06: ÑGreece in New Difficulties" (anonymous); CH,1922/04: "Troubles of the Greek Government" (anonymous); CH,1922/06: "The Murder of Greece by Constantine" (anonymous) and "Venizelos Vindicated" by M. Tsamodos; CH,1922/08: "The Truth about Constantine and Venizelos" by J. Gennadios; TNR,1922/10/04: "The Case for Greece" A. Th. Polyzoides; CH,1923/06: "The Passing of Greek Constitution" by A. Th. Polyzoides.

${ }^{36} \mathrm{CH}$,1921/07: "The Turkish Drift toward Moscow" (anonymous); CH,1922/11: "Russia's Treaty with Turkey" by A. Nazaroff; TAM,1923/05: "Bolshevism from an Eastern Angle" by A. Moore.

37 CH,1920/12: "The Muslim World Today" by J. F. Scheltema; CH,1922/04: "India and Turkish Peace" by S. Hossain and "India and the Moslem Aweking" (anonymous); 1922/05" Anglo-Indian-Turkish Crisis" by $\mathrm{H}$. Woodhouse; TAM,1922/11: "Britain and Islam" by A. Moore; CH,1922/11: "The Nationalist Freemen in Islam" by S. Brodney; TNAR,1923/02: "Islam versus Christianty" by W. Yale; FA,1923/03: "Islam and Britain" by V. Chirol: TAM,1923/04: "Europe versus Asia" by H. E. Wortham.

${ }^{38}$ See for example A,1920/01: "Is the Caliphate in the Melting-Pot" by F. J. Bliss; CH,1921/09: "The Caliphate of Islam" by C. Price; CH,1923/01: "The New Turkish Caliph" by M. Zekeria; A,1923/06: "The Caliphate" A. Toynbee. 
opposition caused by the Kemalist movement was hinted at frequently.

11. Besides the military developments in the region, the bargaining (i.e. negotiations) in the cities of Europe about the new order in the region, in which the Kemalists gradually played a more important role, was closely followed by the American press. ${ }^{39}$ The problem of discord (or the conflict) among the Allied Powers in the region during negotiations about the new arrangements in Turkey was another important issue in the press. ${ }^{40}$ Only one year after the occupation of western Turkey by the Greek armies under the control of the Allied Powers, the discord among them was evident and publicly known. As the Italians were against this occupation from the beginning, and started "secretly" helping the Kemalists, this conflict among the Allied Powers, and the Italian support for the Kemalists were reported regularly by the American press. It was considered a barrier or restriction for Western civilization to punish the Turks as harshly as they had

${ }^{39} \mathrm{CH}, 1919 / 11:$ "Syria and Anglo-French Pact" (anonymous); $\mathrm{CH}, 1920 / 04$ : "The Turks to Stay in Europe" (anonymous); CH,1920/07: "The Turkish Peace Treaty" (anonymous); CH,1920/09: "Signing of the Turkish Peace" (anonymous); CH,1921/01: "TheTurkish Peace Treaty" (anonymous); 1921/01: "Revising the Turkish Treaty" (anonymous); 1921/04: "Greece and the Conference of the Turkish Peace" (anonymous); CH,1921/05: "Bulgaria and the Turkish Treaty" (anonymous); CH,1921/05: "Greece Attempts to Impose the Sevres Treaty" (anonymous); CH,1921/06: "The New Syrian Boundary" (anonymous); CH,1922/05: "The Sevres Treaty Revised" (anonymous); CH,1922/06: "Obstacles to Greco-Turlish Peace" (anonymous).

${ }^{40}$ The press started to publish on this conflict as early as in September 1919: CH,1919/09: "The Passing of Turkish Dominion English-French Conflict"(anonymous). See also CH,1921/05: "Secret Pact of France and Italy" by G. G. Montgomary; CH,1921/07: "The Mistakes of France" by A. Th. Polyzoides; CH,1921/10: "England's Hand in the Near East" by H. C. Flower; CH,1921/11: "France and Kemalist Movement" (anonymous); $\mathrm{CH}, 1922 / 01:$ "France's Pact with Mustafa Kemal" (anonymous) and "Anglo-French Discord in Turkey" H. Woodhouse; CH,1922/04: "The Anglo-French Conflict over Turkey" by H. Woodhouse and "French Policy in the Near East" by J. G. Moskoffian; CH,192/06: "The New Role of France in Europe" by S. Nickolson; CH,1922/07: "Why France is Helping the Turks" by C. Stephanova; CH,1922/09: "The Greco-Allied Crisis in Turkey" (anonymous); TNR,1922/10/04: "British Near East Policy" by A. Toynbee; FA, 1923/06: "Italy and the Mediterranean" F. Coppola. 
deserved. From the autumn 1919, some news about the French opposition to the English initiative in the region and the French attempts to come to an understanding with Kemalists appeared in the press. The open support of the French in the following months for the Kemalists against the Grecks was seen as a last blow to the weak harmony among the Allied Powers, which attested the strong conflict among them.

The role or the responsibilities of the USA in these negotiations was another important issue in the press. ${ }^{41}$

12. In the second half of the period in question, i.e., in 1922 and 1923, when the legitimacy of the Kemalists as the representatives of the people in Turkey was generally accepted in Turkey and abroad, the press started to discuss about the possible future developments in Turkey, in case a Turkish state would be formed. This continued in a higher degree after the foundation of new Turkey. In this context, the economic, commercial and cultural interests of the USA and its citizens in the "new Turkey" became one of the most important issues. ${ }^{42}$

13. After the ultimate defeat of the Greek army on the front in the fall of 1922, the most important topics in the press were the Near East diplomacy and the peace conference at Lausanne. ${ }^{43}$ The

${ }^{41}$ A,1921/07: "The Attitude of the US Toward Europe" by H. Morgenthau; CH,1921/09: "Why We Didn't Declare War on Turkey" by F. Jeweit: TAM,1923/05: "America Must Decide" W. H. Gardiner.

${ }^{42} \mathrm{CH}, 1923 / 03$ : "American Oil Claims in Turkey" H. Woodhouse; CH,1922/09: "The New Turkish Railway Project" (anonymous); CH,1922/10: "Mustafa Kemal and the Americans" by C. Price; CH,1922/11: "American Missionaries in Turkey" by E. P. Wheeler; CH,1923/01: "American School Work in the Near East" by A. W. Staub; TNR,1923/05/09: "Chester \& Co." E. J. Bing; CH,1923/06: "Text of the Chester Concession" (anonymous) and "The Chester Concession as an Aid to New Turkey" by H. Woodhouse; TNAR,1923/06: "The USA and the New Turkey" by H. Armstrong; A,1923/06: "Chester Concession under Fire" by C. A. Moore; CH,1923/09: "Turco-American Treaty" (anonymous); $\mathrm{CH}, 1923$ : "The Turco-American Treaty" (anonymous).

43 "The Loussanne Conference" (anonymous) and "The Near East and Mr. Lloyd George" by A. Moor; TAM,1923/01: "The Return of the Turk" by C. F. G. Masterman; A,1923/02: "The Loussanne Conference" (anonymous) and "Chances and the Cards in Near Eastern Diplomacy" by 
developments were reported regularly, and although the antiTurkish discourse in the NYT and in other periodicals continued, there were always more articles than before in the press, which defended the Kemalists and introduced them as the modern Turkish elite that had proved itself as the Westernized group in Turkey, which was ready to civilize/westernize the country. But the dominant discourse in the press was still anti-Turkish.

14. Apart from these issues, the social, economic and cultural life, ${ }^{44}$ and especially the situation of women ${ }^{45}$ in Turkey were analyzed especially in [A] by some people, who visited the region.

C. Brown; TNR,1923/02/14 "Scvres and Versailles" by A. Toynbee; CH,1923/03: "The Failure of the Loussane Conference" (anonymous); TNR,1923/03/07: "The Break-Down at Lausanne" by A. A. Toynbee; FA,1923/03: "Mr. Lloyd George's Forcign Policy" by H. A. L. Fisher; A,1923/04: "Blind Forces at Lausanne" by C. K. Streit; CH,1923/04: "The Failure of Lausanne Conference" (anonymous); CH,1923/06: "The Progress of the Lausanne Conference" (anonymous);TNR,1923/07/11: "The Week Lausanne Conference" (anonymous); CH,1923/08: "The Eastern Agreement Reached" (anonymous); CH,1923/09: "Signing of Treaty of Lausanne" (anonymous); FA,1923/09: "The East After Lausanne" by A. Toynbec; CH,1923/10: "Peace Terms With Turkey" (anonymous) and "The Near East after Lausanne" by W. S. Davis.

${ }^{44}$ The first article in this context during this period was in A,1919/09: "Industrial Turkey" W. H. Hall. Sce also A,1920/01: "Man and Things as the Turk Sees Them" by H. A. Gibboms; A,1920/01: "New Trails in Trade Blazing the Way in the Near East" by L.Heck: CH,1920/05: "Life in Constantinople Today" by M. Peax; A,1920/07: "New Avenues of Trade in the Near East" by L. Heck; A,1922/02: "Within the Porte Called Sublime" by Demetra Vaka; CH,1922/06: "The Turkish Capitulations" by C. Price; TAM,1923/02: "Civilization and Oil" by L. Pasvolsky; CH,1923/03: "Oil Interests in the Fight for Mosul" by R. L. Bucll; FA,1923/03: "The World Oil Situation" by A. C. Bedford; TNR,1923/05/02: "Concessions and Open Door" by T. W.; FA, 1923/06: "The Capitulations" by P. M. Brown; TNR,1923/07/18: "The Struggle for Mosuls Oil" by E. J. Bing; CH,1923/08: "Turkey's Undeveloped Treasures" by E. J. Bing; A,1923/09: "New Economic Aids in Turkey" by A. Toynbee; $\mathrm{CH}, 1923 / 11$ : "The Turk as a Businessman" by Ziya Bey and Rising Tides of Europe in Turkish Life" by E. J. Bing.

45 A,1919/04: "Days with Veiled Women" E. M. M.; A,1920/01: "Passing of Turkish Harem" B. Millor; CH,1921/02: "The life in a Turkish Harem" L. I. Bigley; A,1922/06: "The Unvciled Women of Istanbul" by Demetra Vaka; CH,1922/10: "Turkish Home Life" by E. Haris; CH,1923/05: 
15. Other issues that found place in the press after the defeat of the Greeks were the migration problem and exchange of the population between Greece and Turkey. ${ }^{46}$

\section{Conclusion}

The period in question (1918-1923) was a kind of "turning point" in the history both of the American foreign policy and of Turkey in general. For the Americans it was a time when their "open door policy" was becoming the dominant policy among the Great Powers in the international arena, and when the American diplomats felt obliged to undertake more responsibility in the settlement of the Eastern Question than before. This was to lead in the future to the abandonment of the then century old Monroe Doctrine.

For Turkey it was the time when a new state was being formed on the "wreckage" of the old Ottoman Empire by the modernist elite, and one of the most important purpose of them was to convince the "Westerners" that they were modern or civilized. To a certain extent these two aspects were linked to each other: The governing Turkish elite (i.e., Kemalists) and the A.merican diplomats were theoretically on the same side, as they both advocated a system, in which "independent" nation-states (instead of the colonies) would make up the "periphery" of the world system. I tend to call the process that was steering the world towards this system, standards of which are determined in the eurocentrist and modern mega-paradigm of the West, "eurocentrist and modern standardization", which, has become gradually more dominant in the last century. The Kemalists were one of the first elite groups in the world, which were conscious of this process and tried hard to make the Westerners, but most of all the Americans, believe their sincerity. It proved to be possible for American diplomats rather more easily than for the American press. The

"Progress of Women in New Turkey" by E. J. Bing; CH,1923/06: "Turkish Woman of Yesterday and Today" by E. J.Bing.

${ }^{45} \mathrm{CH}, 1923 / 03$ : "Solving Greco-Turkish Blood Feuds by Migration" by M. Zekeria; CH,1923/04: "Why Grecks and Turks oppose Being Exchanged" by W. D. Lane. 
politicians in the countries of the Western powers, on the other hand, were divided internally in two groups as well, and those who were still for the previously dominant pre-modern system, treated the Kemalists as enemies to the end.

The attitude of the American press towards the Turkish Question and Turks in general changed very slowly but continuously during the TIW, and this slow change, which was basically positive, was determined strongly by the attempts of the Kemalists to prove how "modern" or "Westernized" they were. Although the anti-Turkish discourse always found its space in the press even after the peace conference in Lausanne, we may say that the weak pro-Turkish voice in the public opinion gradually found more place in the press, and most importantly, a more analytical approach and a more objective point of view started to prevail in the press, which led to a more reserved and careful statements about the Kemalists.

If we compare the evaluation of the way how the Turkish Question was evaluated in the American press with the attitude of those making American foreign policy, by using printed documents on the foreign affairs of that time, ${ }^{47}$ and by using secondary sources based on both published and unpublished documents, ${ }^{48}$ we may conclude that the American policymakers were much more reserved and rational than the press, and that the former reacted more promptly to the change of the content of the

${ }^{47}$ Papers Related to the Foreign Relations of the United States, Washington; Government Printing Office, 1919, 1920, 1921 (Vols. 1 \& 2), 1922 (Vols. 1 \&2) and 1923 (Vols. 1 \&2).

${ }^{48}$ As stated above, it is not the purpose of this paper to discuss "the attitude of the USA towards Turkey in this period" as displayed in these books, but it is worth to refer to some of the most well known ones: John A. De Novo, American Interests and Policies in the Middle East, 1900-1939, Minneapolis, The University of Minnesota Press, 1963; Orhan Duru, Amerikan Gizli Belgeleriyle Türkiye'nin Kurtuluş Yılları, İstanbul, Milliyet Yayınları 1982; Lavrance Evans, United State Policy and the Partition of Turkey, 1914-1924, Baltimore, 1965; James Gordon, American Relations with Turkey, 1830-1930, Philadelphia, University of Penslvania Press, 1932; Joseph Grabill, Protestant Diplomacy and the Near East, Minneapolis, The University of Minnesota Press, 1971 and Roger R. Trask, The United States, Turkish Nationalism and Reform, 1914-1939, Minneapolis, University of Minnesota Press, 1971. 
news from the region. As the ambivalence in the attitude of the American statesmen made them wait and see the developments in the region and take decisions according to these developments, this helped them to be prepared for every possible outcome. By doing so they guaranteed American political and economic interests under every possible circumstance, no matter which party would win in the struggle for the region.

In this context, the Americans who were close to the Kemalists had more opportunity to follow the recent developments in Ankara and this was one of the reasons why they were supporting the Kemalists in their efforts to form a new state in the region. But the politicians, who were not aware of the current situation in the region and did not know the facts about the region well, could be influenced easily by the anti-Turkish lobbies in the US. Among them were people like Morgenthau, who identified the new Turkish state in Ankara with the pre-modern one in İstanbul, which existed in the time of their service as diplomats there.

The place of "the settlement of the Turkish question in the American press" needs to be researched more deeply and a comparison of the results of this analysis with the attitude of the American statesmen may lead to very interesting consequences. However, the issue of the mutual influence of each of these on the other would remain the most interesting subject, which necessitates an even more precise study of the press of that time and of its role in the making of the American forcign policy. 